\title{
"Free" Diaminopimelic Acid and Deoxyribonucleic Acid Homology of Lactobacillus helveticus
}

\author{
F. DEllaglio, M. VESCOVO, and L. PREMI \\ Istituti di Microbiologia Agraria e Tecnica e Microbiologia Lattiero-Casearia, \\ Università Cattolica del Sacro Cuore, Piacenza, Italy
}

\begin{abstract}
Thirty-eight strains of Lactobacillus helveticus, including 26 strains of $L$. helveticus biotype jugurti, were isolated from natural starters for Grana cheese. Seventeen strains had diaminopimelic acid (DAP) as a cytoplasmic (but not cell wall) component; 21 strains did not contain DAP. DAP-positive and galactose-negative strains may constitute new biotypes of $L$. helveticus. Despite these variations, all of the strains studied displayed high deoxyribonucleic acid (DNA)-DNA homologies to the reference DNA, and the presence or absence of DAP is not considered to be of great taxonomic importance in $L$. helveticus.
\end{abstract}

During the past 10 years, detailed investigations on the homofermentative, thermophilic lactobacilli normally present in natural whey starters for Grana cheese have been undertaken at our Institute. It has been found (3) that Lactobacillus helveticus (including its biotypes) constitutes the species responsible for the lactic acid fermentation in Grana cheese, although small numbers of strains of $L$. bulgaricus, $L$. lactis, and Streptococcus thermophilus are also present. The most frequently occurring strains have unusual properties such as: (i) high proteolytic activity (2); (ii) sensitivity to xanthine and guanine (1); (iii) inability to produce normal amounts of lactic acid in milk $(3,13)$; (iv) presence of "free" diaminopimelic acid (DAP) as a cytoplasmic, but not as a cell-wall, component (4); (v) inability to ferment galactose; (vi) cell morphology variation (18); and (vii) optimal growth temperatures different from those of previously described strains.

Despite wide differences in the quantities of lactic acid produced by strains of $L$. jugurti from Grana cheese starters, Matteuzzi (14) demonstrated high deoxyribonucleic acid (DNA)-DNA homologies (89 to $100 \%$ ) in all strains. The purpose of this investigation was to determine the extent of DNA-DNA homology among phenotypically different strains of $L$. helveticus, especially those that differ with respect to DAP production and galactose fermentation.

\section{MATERIALS AND METHODS}

Bacterial strains. The strains are listed in Table 1. They were isolated from whey cheese starters obtained from different dairies producing Grana cheese. All of the organisms were cultured in MRS broth (7).

Methods. The identities of the strains were determined on the basis of the criteria established by the Subcommittee on the Taxonomy of the Lactobacilli and Closely Related Organisms of the International Committee on Systematic Bacteriology.

Cells were treated with acetic acid $(10 \% \mathrm{vol} / \mathrm{vol})$, and the extracted "free" DAP was determined by the paper chromatography method of Hoare and Work (10).

Cells for DNA extraction were washed twice with saline-ethylenediaminetetraacetic acid (EDTA) $(0.15$ $\mathrm{M} \mathrm{NaCl}$ plus $0.1 \mathrm{M}$ EDTA, pH 8) and, since it was difficult to lyse the organisms, a dual system of lysozyme and Pronase was used (6). The isolation and purification of DNA was performed according to the procedure described by Marmur (12). The mole percent of guanine plus cytosine $(\% \mathrm{G}+\mathrm{C})$ in the DNA of duplicate samples was determined by the thermal melting procedure using equation 9 or 10 of De Ley (5) for calculation. DNA-DNA hybridization was carried out with the single-point competition version of Johnson and Ordal (11) as described in our previous paper (6).

\section{RESULTS AND DISCUSSION}

The 38 strains of Lactobacillus studied had the physiological characters of $L$. helveticus; 26 of them were considered to be maltose-negative 
TABLE 1. Fermentation pattern, free $D A P, \% G+C$, and $D N A$ homology among $D A P$-positive and -negative strains of Lactobacillus helveticus

\begin{tabular}{|c|c|c|c|c|c|c|}
\hline \multirow[b]{2}{*}{$\begin{array}{l}\text { Bacterial } \\
\text { strain }\end{array}$} & \multicolumn{2}{|c|}{ Fermentation of } & \multirow[b]{2}{*}{$\begin{array}{l}\text { Free } \\
\text { DAP }\end{array}$} & \multirow[b]{2}{*}{$\begin{array}{l}\mathrm{Mol} / \\
\mathrm{G}+\mathrm{C}\end{array}$} & \multicolumn{2}{|c|}{ DNA homology relative to strains: } \\
\hline & maltose & galactose & & & $\mathrm{Mb} 66$ (DAP+) & Mb 68 (DAP-) \\
\hline \multicolumn{7}{|c|}{$\begin{array}{l}\text { L. helveticus } \\
\text { biotype jugurti }\end{array}$} \\
\hline $\mathrm{Mb} 66$ & - & - & + & 38.2 & 100 & 98 \\
\hline $\mathrm{Mb} 83$ & - & - & + & 38.4 & 81 & 91 \\
\hline $\mathrm{Mb} 88$ & - & - & + & 39.8 & 86 & 80 \\
\hline $\mathrm{Mb} 136$ & - & - & + & 39.1 & 80 & 96 \\
\hline Mcb 6 & - & + & + & 38.4 & 93 & 95 \\
\hline Mcb 7 & - & + & + & 38.7 & 81 & 81 \\
\hline Mcb 27 & - & + & + & 38.5 & 88 & 98 \\
\hline Mcb 33 & - & - & + & 38.4 & 82 & 90 \\
\hline $\operatorname{Mco} 4$ & - & - & + & 37.9 & 74 & 78 \\
\hline Mco 44 & - & - & + & 38.3 & 82 & 89 \\
\hline Mco 46 & - & + & + & 38.9 & 99 & 96 \\
\hline W 86 & - & + & + & 38.6 & 82 & 94 \\
\hline i 160 & - & + & + & 40.1 & 89 & 86 \\
\hline M 699 & - & + & + & 39.2 & 87 & 88 \\
\hline M 481 & - & + & + & 38.8 & 92 & 85 \\
\hline Mb 68 & - & + & - & 39.1 & 97 & 100 \\
\hline $\mathrm{Mb} 64$ & - & - & - & 38.6 & 92 & 91 \\
\hline $\operatorname{Mcb} 2$ & - & + & - & 39.0 & 96 & 94 \\
\hline $\operatorname{Mcb} 12$ & - & - & - & 39.3 & 83 & 94 \\
\hline Mcb 26 & - & + & - & 37.9 & 81 & 91 \\
\hline $\operatorname{Mco} 33$ & - & - & - & 38.7 & 79 & 84 \\
\hline Mco 42 & - & - & - & 39.2 & 81 & 76 \\
\hline Ms 5 & - & + & - & 38.2 & 78 & 81 \\
\hline Mau 121 & - & - & - & 38.5 & 86 & 94 \\
\hline Mca 56 & - & - & - & 38.1 & 80 & 86 \\
\hline Mca 61 & - & - & - & 38.6 & 87 & 80 \\
\hline \multicolumn{7}{|l|}{ L. helveticus } \\
\hline AH 5 & + & + & + & 40.4 & 90 & 85 \\
\hline WL 1 & + & + & + & 39.2 & 92 & 87 \\
\hline Mcb 35 & + & + & - & 38.1 & 84 & 91 \\
\hline $\mathrm{Mb} 91$ & + & - & - & 38.9 & 82 & 95 \\
\hline H 1 & + & + & - & 37.5 & 96 & 90 \\
\hline H 4 & + & + & - & 38.6 & 97 & 95 \\
\hline H 5 & + & + & - & 37.4 & 100 & 99 \\
\hline H 18 & + & + & - & 37.5 & 95 & 89 \\
\hline M 46 & + & + & - & 38.1 & 92 & 98 \\
\hline P 72 & + & + & - & 38.4 & 99 & 95 \\
\hline V 89 & + & + & - & 37.9 & 88 & 95 \\
\hline V 90 & + & + & - & 38.7 & 97 & 98 \\
\hline
\end{tabular}

biotypes of $L$. jugurti. The maltose and galactose fermentation results, the presence of free $\mathrm{DAP}$, the $\% \mathrm{G}+\mathrm{C}$, and the genetic homology values among DAP-positive and -negative strains are reported in Table 1. Surprisingly, 15 strains were atypical in that they did not ferment galactose.

The presence of free, i.e., cytoplasmic, DAP in $L$. helveticus strains is thought to result from a disturbance in the regulation of lysine biosynthesis (3). DAP is frequently present in strains of this species isolated from Grana cheese starters ( 17 of 38 strains). Moreover, the presence of DAP-positive strains in starters varies from dairy to dairy (4).

The $\mathrm{G}+\mathrm{C}$ values (37.4 to $40.4 \mathrm{~mol} \%$ ) are in good agreement with those previously reported by Gasser and Mandel (8), Miller et al. $(15,16)$, Simonds et al. (17), and Dellaglio et al. (6).

The DNA-DNA hybridization experiments show that all of the strains, regardless of DAP content, display high genetic homology to the reference organisms. For instance, L. helveticus biotype jugurti $\mathrm{Mb} 66$ was DAP positive and 
$\mathrm{Mb} 68$ was DAP negative, yet the DNA-DNA homologies ranged from 74 to $100 \%$ and from 76 to $100 \%$, respectively. Hence, the presence or absence of cytoplasmic DAP, although possibly of some taxonomic significance, does not reflect any important genetic difference among the organisms studied.

\section{ACKNOWLEDGMENTS}

This investigation was supported by research grant 71.02253.06 of the Consiglio Nazionale delle Ricerche, Roma. We are grateful to V. Bottazzi for his valuable advice.

\section{REPRINT REQUESTS}

Address reprint requests to: Dr. Franco Dellaglio, Istituto di Microbiologia Agraria e Tecnica, Facoltà di Agraria, Piacenza, Italia.

\section{LITERATURE CITED}

1. Bottazzi, V. 1962. Effect of purines upon the growth in milk of Lactobacillus lactis. XVIth Int. Dairy Congr. Sect. III 2:331-334.

2. Bottazzi, V. 1962. Proteolytic action of some strains of thermophilic lactobacilli. XVIth Int. Dairy Congr. Sect. VI 1:522-528.

3. Bottazzi, V., M. Vescovo, and F. Dellaglio. 1973. Ricerche sulla microbiologia del formaggio Grana. Parte IX. Caratteri e distribuzione dei biotipi di $L$. helveticus nelle colture associate naturali (siero-fermento). Sci. Technol. Latt.-Cas. 24:23-39.

4. Bottazzi, V., N. Weiss, and O. Kandler. 1967. Anreicherung freier Diaminopimelinsaure in Lactobacillen. Arch. Mikrobiol. 58:3541.

5. De Ley, J. 1970. Reexamination of the association between melting point, buoyant density, and chemical base composition of deoxyribonucleic acid. J. Bacteriol. 101:738-754.

6. Dellaglio, F., V. Bottazzi, and L. D. Trovatelli. 1973. Deoxyribonucleic acid homology and base composition in some thermophilic lactobacilli. J. Gen. Microbiol. 74:289-297.

7. De Man, J. C., M. Rogosa, and M. E. Sharpe. 1960. A medium for the cultivation of lactobacilli. J. Appl, Microbiol. 23:130-136.

8. Gasser, F., and M. Mandel. 1968. Deoxyribonucleic acid base composition of the genus Lactobacillus. J. Bacteriol. 96:580-588.

9. Hansen, P. A. 1968. Type strains of Lactobacillus species. Report by the Taxonomic Subcommittee on Lactobacilli and Closely Related Organisms. American Type Culture Collection, Rockville, Md.

10. Hoare, D. S., and E. Work. 1957. The stereoisomers of $\alpha-\epsilon$ diaminopimelic acid. II. Their distribution in the bacterial order Actinomycetales and in certain Eubacteriales. Biochem. J. 65:441-447.

11. Johnson, J. L., and E. J. Ordal. 1968. Deoxyribonucleic acid homology in bacterial taxonomy: effect of incubation temperature on reaction specificity. J. Bacteriol. 95:893-900.

12. Marmur, J. 1961. A procedure for the isolation of deoxyribonucleic acid from microorganisms. J. Mol. Biol. 3:208-218.

13. Matteuzzi, D. 1967. Studi sulla microflora dei siero-innesti del formaggio parmigiano-reggiano. Distribuzione biometrica dei caratteri "potere proteolitico" e "potere acidogeno" nella specie Lactobacillus jugurti. Ann. Microbiol. 17:211219.

14. Matteuzzi, D. 1972. Lactic acid production in milk and DNA homology relationship in the species Lactobacillus jugurt. Can. J. Microbiol. 18:1893-1895.

15. Miller, A., III, W. E. Sandine, and P. R. Elliker. 1970. Deoxyribonucleic acid base composition of lactobacilli determined by thermal denaturation. J. Bacteriol. 102:278-280.

16. Miller, A., III, W. E. Sandine, and P. R. Elliker. 1971. Deoxyribonucleic acid homology in the genus Lactobacillus. Can. J. Microbiol. 17:625630.

17. Simonds, J., P. A. Hansen, and S. Lakshmanan. 1971. Deoxyribonucleic acid hybridization among strains of lactobacilli. J. Bacteriol. 107:382-384.

18. Vescovo, M., V. Bottazzi, F. Dellaglio, and B. Battistotti. 1971. Su alcuni caratteri culturali e morfologici di ceppi di Lactobacillus jugurti. Ann. Microbiol. 21:15-23. 